\title{
MENGUNGKAP RAHASIA DIBALIK ANGKA PENDAPATAN (METODE STUDI KRITIS)
}

\author{
Bambang Haryadi \\ haryadirahman73@gmail.com \\ FEB Universitas Trunojoyo Madura
}

\begin{abstract}
Revenue for the company is very important. The greater income earned, the greater company's ability to fund all costs incurred. In practice, the value of income can not stand alone from the environment. This study wants to reveal the secrets behind the rising of corporate income. The paradigm used in this research is qualitative. This paradigm considers that reality is subjective and has many dimensions. The research approach uses a critical study that aims to reveal the meaning behind income numbers. This critical study is a Neo Marxist line. The results showed that: (1) the increase of income value can not be separated from the interests of management. The company's revenue value so far is a reflection of the company's strategy by using tariff increase only. Furthermore, (2) the company's revenue also shows the obligation of the company to deposit the PAD to the local government. (3) Increase in revenues has a negative impact on consumers. Increasing tariffs to earn revenue was not followed by providing good service to customers. (4) In increasing revenue, companies should not ignore environmental awareness and sustainability.
\end{abstract}

Key words: revenue; tariff; customer; critical study

\section{ABSTRAK}

Pendapatan bagi perusahaan sangat penting maknanya, semakin besar pendapatan yang diperoleh maka semakin besar pula kemampuan perusahaan untuk mendanai seluruh biaya yang timbul. Dalam prakteknya, angka-angka pendapatan tidak dapat berdiri sendiri dari lingkungannya. Studi ini berupaya mengungkap rahasia di balik meningkatnya pendapatan perusahaan. Paradigma yang digunakan dalam penelitin ini adalah kualitatif. Paradigma ini memandang bahwa realitas bersifat subjektif dan berdimensi banyak. Pendekatan penelitian mengunakan studi kritis yang bertujuan untuk mengungkap makna di balik angka pendapatan. Studi kritis ini merupakan aliran Neo Marxis. Hasil penelitian menunjukkan bahwa: (1) meningkatnya angka pendapatan perusahaan tidak dapat dipisahkan dari kepentingan manajemen. Angka pendapatan perusahaan selama ini merupakan refleksi dari strategi perusahaan dengan menggunakan kenaikan tarif saja. Selanjutnya (2) pendapatan perusahaan juga menunjukkan keharusan perusahaan menyetor PAD kepada Pemda setempat. (3) Meningkatnya pendapatan ternyata membawa dampak buruk terhadap konsumen. Peningkatan tarif untuk memperoleh pendapatan ternyata tidak diikuti dengan pemberian pelayanan yang baik kepada pelanggan. (4) Dalam meningkatkan pendapatan, perusahaan tidak boleh mengabaikan kepedulian dan kelestarian terhadap lingkungan.

Kata kunci: pendapatan, tarif, pelanggan, studi kritis

\section{PENDAHULUAN}

Dalam paradigma akuntansi positif, angka-angka akuntansi merupakan cermin realitas fisik serta sebagai potret atas faktafakta sosial yang bebas nilai (Jurdi, 2011). Bebas nilai yang dimaksud di sini adalah bebas dari nilai ilmu pengetahuan, peng- alaman, sifat, kepentingan dan nilai masyarakat (Triyuwono, 2000), bebas dari nilai agama, sosial, moral, politik, kepentingan dan nilai ekonomi. Keseluruhannya melekat secara inheren dalam diri akuntan yang menyusun angka tersebut. Ini mengandung maksud bahwa angka-angka akuntansi 
tersebut merupakan angka yang disusun berdasarkan situasi dan kondisi perusahaan yang senyatanya. Angka ini tidak dipengaruhi dari berbagai nilai dan kepentingan para penyusun laporan keuangan. Angka akuntansi sangat objektif dan netral menggambarkan kondisi perusahaan apa adanya.

Namun demikian, dalam prakteknya angka-angka akuntansi tersebut termasuk didalamnya pendapatan tidak dapat berdiri sendiri dari lingkungan di mana akuntansi itu dioperasikan. Akuntansi akan senantiasa dipengaruhi oleh lingkungannya (Hopwood, 1978). Hal ini terbukti dengan banyaknya hasil penelitian yang menunjukkan bahwa ternyata akuntansi terbentuk dari lingkungan budaya masyarakat, sistem ekonomi, sistem politik, dan sistem sosial (Bailey, 1988; Tinker et al., 1982; Gamble, 1995).

Di samping dipengaruhi oleh lingkungan, ternyata akuntansi juga memiliki kemampuan untuk mempengaruhi dan bahkan membentuk lingkungan di mana ia dipraktikkan. Bahkan Triyuwono (2006) menyatakan bahwa akuntansi memiliki peran yang sangat penting dalam mempengaruhi dan membentuk perubahan organisasi. Tiga peranan umum akuntansi dalam proses perubahan organisasi yaitu bagaimana akuntansi menciptakan visibilitas dalam sebuah organisasi, bagaimana akuntansi berfungsi sebagai praktik kalkulasi dan bagaimana akuntansi menciptakan domain untuk aksi ekonomi.

Tinker (1980) melihat bahwa akuntansi pada hakekatnya sebagai anak dari budaya dimana akuntansi itu berada. Artinya bahwa akuntansi sebagai suatu ilmu maupun praktek dibentuk melalui interaksi sosial yang sangat komplek (Hines, 1988; Francis, 1990). Jika lingkungan yang membentuk akuntansi tersebut adalah lingkungan kapitalisme, maka perkembangan akuntansi sebagai ilmu dan prakteknya akan bernafaskan kapitalisme juga (Komala, 2015; Priyastiwi, 2016; Apriyanti, 2017; Riyansyah, 2017). Bailey (1988) dan Setijaningsih (2012) memperkuat pernyataan ini dengan menunjukkan bahwa akuntansi yang dipraktekan di negaranegara sosialis sangat dipengaruhi oleh faktor budaya masyarakat, sistem ekonomi, sistem sosial, sistem politik serta bentukbentuk organisasi di negara setempat. Hasil ini menjadi bukti bahwa ternyata akuntansi yang dipraktikkan di Negara Sosialis tersebut sangat sarat dengan nilai-nilai.

Menurut Komala (2015) ilmu akuntansi sebagai ilmu sosial dalam prakteknya tidak dapat dipisahkan dengan budaya kapitalisme. Akuntansi telah dimanfaatkan oleh para praktisi untuk memuluskan jalannya membentuk suatu budaya bisnis yang penuh dengan budaya kapitalisme dan menghasilkan kinerja sesuai keinginannya. Sesungguhnya akuntansi tidaklah bebas nilai, sebagai bagian dari ilmu sosial perkembangan ilmu akuntansi telah terjerembab ke dalam praktek dan perkembangan ilmu yang sarat dengan unsur subjektivitas, maskulin dan menghalalkan segala cara dan penuh dengan perilaku tidak etis yang merupakan wujud nyata dari budaya kapitalisme (Brown dan Ball, 1967).

Berdasarkan fakta ini perlu dipertanyakan kembali jika dikatakan bahwa angka-angka akuntansi antara lain jumlah angka pendapatan, beban serta jumlah keuntungan atau kerugian yang diperoleh adalah bebas nilai adanya. Pada kenyataannya angka-angka kinerja itu tidak pernah bisa lepas dari kepentingan pihak-pihak penyusun laporan keuangan tersebut.

Sebagaimana dinyatakan Irianto (2006) bahwa angka akuntansi misalnya laba pada hakekatnya merupakan sesuatu yang dikonstruk sedemikian rupa, sehingga input yang sama dapat dihasilkan beragam laba jika digunakan metode yang berbeda. Laba (rugi) adalah "simbol yang diciptakan" yang memiliki akar kepentingan tertentu. Bahwasanya pelestarian pengkeramatan laba hanya akan membesarkan satu atau lebih kelompok kepentingan tertentu sementara memarginalkan dan bahkan menghancurkan yang lainnya. Akuntansi selama ini hanya berbasis pada kepentingan para pemegang saham (shareholders). Kepedulian 
akuntansi terhadap mereka diutamakan dalam membantu pengambilan keputusan mengenai pendapatan, kekayaan dan peningkatan kinerja (Beaver, 1966).

Besarnya pengaruh lingkungan sangat tergantung dari kompleksitas permasalahan bisnis yang dijalankan oleh perusahaan bersangkutan. Semakin komplek tentu semakin besar pula faktor-faktor yang mem pengaruhi laba atau kinerja perusahaan tersebut. Bagi perusahaan publik, tentu kompleksitas permasalahan semakin luas dikarenakan banyak pihak yang memiliki kepentingan terhadap keberadaan perusahaan publik ini. Nuansa kepentingan ekonomi, kepentingan politik dan kepentingan lain dari berbagai pihak setiap saat muncul dan menyatu dalam perusahaan publik (Mulawarman, 2013; Sugiono, 2014; Priyastiwi, 2016). Oleh karena itu sungguh sangat tepat jika dalam penelitian ini perusahaan air (PDAM) dijadikan sebagai objek penelitian untuk mengungkap pengaruh-pengaruh serta kepentingan-kepentingan yang ada dalam kinerja (laba/rugi) yang dihasilkan. Terlebih lagi PDAM di Indonesia jumlahnya cukup banyak dan secara keseluruhan kinerja yang diperoleh relatif sama yaitu masuk dalam kategori rendah dan banyak permasalahan mendasar yang belum tertangani. PDAM dibentuk berdasarkan Undang-Undang Nomor 5 tahun 1962. Sebagai penyelenggara utama pelayanan air minum di daerah di samping mengemban misi komersial PDAM juga berperan sebagai pengatur dan penentu kebijakan sebagai operator. Sebagai penyelenggara utama pelayanan air minum di daerah di samping mengemban misi komersial PDAM juga berperan sebagai pengatur dan penentu kebijakan sebagai operator.

PDAM memiliki kesempatan untuk dapat meningkatkan konstribusi terhadap upaya pemerintah daerah meningkatkan pendapatan asli daerah. Dengan pola perusahaan monopoli PDAM dapat dengan lebih leluasa menentukan tarif, meningkatkan jumlah pelanggan dan memperoleh sumber-sumber air untuk diolah menjadi air minum. Dengan sistem ini pula PDAM bisa dijadikan target untuk memberikan kontribusi pendapatan yang besar kepada pemerintah daerah dan menjadi penyokong utama sumber-sumber pendapatan asli di masing-masing daerah.

Dalam perjalanannya berdasarkan kajian literatur (Perpamsi, 2010) menunjukkan bahwa berbagai permasalahan PDAM yang tidak kunjung selesai meliputi: pertama, pemerintah belum menerapkan pengelolaan PDAM secara profesional. Dampaknya adalah air minum saat ini baru dapat dinikmati oleh sebagian kecil masyarakat Indonesia. Secara nasional, cakupan air perpipaan baru sekitar 17\%, meliputi 32\% di perkotaan dan $6,4 \%$ di perdesaan. Adapun tingkat pelayanan yang diberikan relatif rendah, kehilangan air tinggi (41\%). Biaya produksi sangat tergantung dari sumber air baku yang digunakan oleh PDAM, namun secara umum biaya produksi untuk semua jenis air baku ternyata lebih tinggi daripada tarif.

Sebagaimana dijelaskan diatas bahwa menggunakan PDAM sebagai objek penelitian sangat tepat, terlebih lagi dengan pendekatan studi kritis yang berupaya mengungkap pengaruh-pengaruh serta kepentingan-kepentingan yang muncul di balik angka pendapatan (kinerja) yang dihasilkan. Peneliti berkeyakinan bahwa angka pendapatan perusahaan tidak bisa berdiri sendiri dan tentu akan selalu dipengaruhi oleh banyak kepentingan dan motivasimotivasi internal dan eksternal.

Di Balik angka pendapatan sebagai contoh, ternyata perusahaan acap kali mengabaikan pelayanan dan kepentingan pelanggan, keluhan pelanggan sering tidak ditanggapi dengan baik oleh PDAM, pelanggan merasa tidak berdaya. Hal ini menandakan kedudukan antara konsumen dan produsen tidak setara. Walaupun di beberapa PDAM sudah terbentuk forum pelanggan/konsumen, namun perannya belum maksimal, belum dianggap mitra kerja PDAM yang potensial. Pengawasan/ akuntabititas terhadap pengelolaan penyedia air minum masih lemah, belum ada 
sanksi untuk penyelenggara air minum yang tidak memberikan pelayanan sesuai dengan syarat yang ditentukan.

Kebijakan yang memihak kepada masyarakat miskin masih belum perkembang. Pada dasarnya negara menjamin hak setiap orang untuk mendapatkan air bagi kebutuhan pokok minimal sehari hari guna memenuhi kehidupan yang sehat, bersih dan produktif (UU No 7 tahun 2004, pasal 10). Pada kenyataannya presentase penduduk miskin masih tinggi, sehingga kemampuan untuk mendapat akses kesarana penyediaan air minum yang memenuhi syarat masih terbatas.

Masyarakat berpenghasilan rendah, ternyata membayar lebih besar untuk memperoleh air daripada masyarakat berpenghasilan tinggi, hal ini menunjukkan ketidak adilan dalam mendapatkan akses pada air minum. Walaupun sudah terdapat programprogram air minum dan sanitasi untuk masyarakat verpenghasilan rendah, namun akses terhadap air minum belum menunjukkan peningkatan yang berarti. Perlu dukungan kebijakan yang lebih fokus untuk penyediaan sanitasi dan air minum bagi masyarakat berpenghasilan rendah.

\section{TINJAUAN TEORETIS}

\section{Definisi dan Makna Pendapatan}

Financial Accounting Standards Boards (FASB) menyatakan bahwa pendapatan pada hakekatnya merupakan kenaikan atau arus masuk perusahaan pada nilai harga satuan usaha atau penghentian hutanghutang atau kombinasi dari keduanya dalam satu periode yang diperoleh dari penyerahan/produksi barang-barang, penyerahan jasa dan pelaksanaan aktivitas ekonomi lainnya, sedangkan menurut Standar Akuntansi Keuangan PSAK 23 (Ikatan Akuntan Indonesia, 2016) pendapatan merupakan arus masuk bruto dari manfaat ekonomi yang timbul dari aktivitas normal perusahaan selama suatu periode bila arus masuk itu mengakibatkan kenaikan ekuitas yang tidak berasal dari kontribusi penanam modal. Jenis pendapatan sangat tergantung dari jenis perusahaannya. Tidak semua perusahaan memiliki jenis pendapatan yang sama karena aktivitas usahanya juga berbeda-beda. Perusahaan industri memperoleh pendapatan karena aktivitas memproduksi bahan baku menjadi bahan jadi, perusahaan dagang memperoleh pendapatan karena aktivitas menjual barang dagangannya, serta perusahaan jasa karena aktivitas memberikan pelayanan jasa kepada pelanggan kemudian memperoleh pendapatan atas jasa yang telah diberikan.

Pendapatan bagi perusahaan sangat penting maknanya, semakin besar pendapatan yang diperoleh maka akan semakin besar pula kemampuan perusahaan untuk mendanai seluruh biaya-biaya yang timbul dari aktivitasnya. Angka pendapatan sebagaimana tercermin dalam laporan keuangan merupakan produk dari akuntansi. Pendapatan adalah salah satu unsur pengukuran kinerja perusahaan.

\section{Teori Kritis, Riset Angka Pendapatan dan Lingkungan}

Teori kritis yang muncul pada tahun 1920 dan dipengaruhi oleh dua pemikiran utama, yaitu pertama teori kritis Frankfurt School, yang sumber-sumber pemikirannya bisa dilacak dari pemikiran-pemikiran Habermas, Adorno, dan Max Horkheimer, serta didukung oleh pemikir-pemikir lain seperti Herbert Marcuse, Walter Benjamin, Eric Fromm, Albrecht Wellmer, Karl-Otto Apel, dan Axel Honneth. Kedua, pengaruh dari karya dan pemikiran Antonio Gramsci (Demirovic, 2009; Agustianto, 2013; Iwan, 2014; Donatus, 2015). Teori kritis muncul pada saat adanya pemikiran-pemikiran yang sangat kritis terhadap pemikiran Karl Mark dan penerusnya. Pemikiran-pemikiran ini pada gilirannya muncul menjadi sebuah mahzab yang dikenal dengan mahzab Frankfurt dimana merupakan perkembangan lebih lanjut dari Marxisme barat.

Studi kritis yang digunakan merupakan aliran Neo Marxis. Aliran ini masuk dalam aliran kontemporer yang berbasis pada filsafat Marx dalam menghadapi situasi 
masyarakat industri maju saat itu. Aliran ini juga disebut dengan mahzab Frankfurt yang didirikan oleh Felix Well pada tahun 1923. Filsafat Neo Marxisme ini dilatarbelakangi oleh sikap reaksi terhadap kebanggaan atas kesuksesan pembangunan fisik saat itu, padahal di pihak lain masyarakat saat itu mengalami kekosongan jiwa dan batin sebagai produk dari sistem kapitalisme yang berlaku saat itu (Donatus, 2015). Di balik keberhasilan industrialisasi saat itu ternyata menyimpan banyak dampak negatif yaitu alienasi manusia dimana mereka mengalami keterasingan dengan lingkungannya. Sifat individualism berkembang, semua mengejar kepentingan dan kebutuhan dirinya sendirisendiri. Persaingan bebas sudah tidak lagi mempedulikan kepentingan bersama dan orang lain. Dengan kata lain fenomena keberhasilan itu telah menciptakan suasana pengabaian manusia sebagai makhluk sosial. Hal yang terjadi adalah hubungan sesama manusia sudah tidak lagi dipandang sebagai hubungan antar pribadi namun menjurus kepada masalah kepentingan semata.

Teori kritis adalah sebuah metodologi yang berdiri di dalam ketegangan dialetis antara filsafat dan ilmu pengetahuan. Dalam ketegangan itulah, teori kritis tidak berhenti pada fakta objektif sebagaimana dalam positivisme. Teori kritis hendak menembus realitas sosial sebagai fakta sosiologis, untuk menemukan kondisi-kondisi yang bersifat transedental yang melampaui data empiris. Dari kutub ilmu pengetahuan dimaksudkan bahwa teori kritis bersifat historis dan tidak meninggalkan data yang diberikan oleh pengalaman kontekstual. Dengan demikian teori kritis tidak hendak jatuh pada metafisika yang melayang-layang. Teori ini merupakan dialektika antara pengetahuan yang bersifat transedental dan yang bersifat empiris (Raco, 2011). Hasil penelitian Hopwood (1978) dan Kieso et al. (2014) telah membutkikan bahwa ternyata angka akuntansi termasuk pendapatan tidak dapat berdiri terpisah dari aspek lingkungan dimana perusahaan tersebut berada. Bahkan akuntansi itu sendiri ternyata bisa terbentuk dari lingkungan budaya masyarakat, sistem ekonomi, sistem politik, dan sistem sosial (Bailey, 1988; Burchell et al., 1985).

Demikian pula Watts dan Zimmerman (1986) mengakui bahwa sistem ekonomi kapitalis tempat dimana akuntansi dipraktikkan memiliki pengaruh sangat besar terhadap warna dan corak akuntansi. Mackevicius (2005) juga menggambarkan tentang sistem akuntansi yang berbasis sistem ekonomi sosialis, sedangkan Triantoro (2008) ilmu akuntansi sebagai ilmu sosial dalam prakteknya tidak dapat dipisahkan dengan budaya kapitalisme. Akuntansi telah dimanfaatkan oleh para praktisi untuk memuluskan jalannya membentuk suatu budaya bisnis yang penuh dengan budaya kapitalisme dan menghasilkan kinerja sesuai keinginannya.

\section{METODE PENELITIAN}

\section{Paradigma dan Metode Analisis Penelitian}

Paradigma dalam penelitian merupakan suatu rerangka berpikir yang dapat menjelaskan bagaimana cara pandang peneliti terhadap fakta kehidupan sosial dan perlakuan peneliti terhadap sebuah ilmu atau teori (Juliandi dan Manurung, 2014; Yusuf, 2016). Paradigma penelitian juga menjelaskan bagaimana peneliti memahami suatu masalah, kriteria pengujian sebagai landasan untuk menjawab masalah penelitian. Penelitian ini menggunakan paradigma kualitatif atau pendekatan naturalistik atau konstruktifis (Juliandi dan Manurung, 2014; Setyosari, 2016). Paradigma kualitatif dinamakan juga dengan pendekatan naturalistik atau konstruktifis. Paradigma ini meliputi pendekatan kritis, interpretif dan post modern. Paradigma ini dibangun berlandaskan paradigma fenomenologis dari Edmund Husserl (18591926). Paradigma kualitatif adalah satu model penelitian humanistik, yang menempatkan manusia sebagai subyek utama dalam peristiwa sosial atau budaya. Sifat humanis dari aliran pemikiran ini terlihat dari pandangan tentang posisi manusia sebagai penentu utama perilaku individu 
dan gejala sosial. Dalam paradigma kualitatif (naturalistic paradigm) memandang bahwa realitas itu bersifat subjektif dan berdimensi banyak. Paradigma kualitatif memandang bahwa peneliti berinteraksi dengan fakta yang diteliti sehingga lebih bersifat subjektif, tidak bebas nilai dan bias. Paradigma ini memandang realitas sosial dalam berbagai banyak dimensi (Juliandi dan Manurung, 2014; Nurhayati, 2015; Batubara, 2017). Paradigma ini dilandasi oleh pendekatan naturalistik untuk mencari dan menemukan pengertian atau pemahaman tentang fenomena dalam suatu latar yang berkonteks khusus. Oleh karena itu maka pendekatan ini juga mampu menelusuri data secara lebih mendalam hingga ke akar permasalahan.

Pendekatan yang digunakan dalam penelitian ini adalah studi kritis yang merupakan aliran Neo Marxis. Aliran ini masuk dalam aliran kontemporer yang berbasis pada filsafat Marx yang dikembangkan oleh Felix Well pada tahun 1923. Studi kritis merupakan salah satu pendekatan dalam paradigma kualitatif disamping pendekatan interpretif dan postmodernis (Chua, 1986; Burrel dan Morgan, 1979). Teori kritis muncul pada saat adanya pemikiran-pemikiran yang sangat kritis terhadap pemikiran Karl Mark dan penerusnya. Pemikiran-pemikiran ini pada gilirannya muncul menjadi sebuah mahzab yang dikenal dengan mahzab Frankfurt dimana merupakan perkembangan lebih lanjut dari Marxisme barat.

Studi kritis berupaya mencari makna di balik yang empiris, dan menolak adanya konsep valuefree. Studi kritis mempunyai komitmen yang tinggi kepada tata sosial yang lebih adil. Asumsi dasarnya adalah bahwa ilmu sosial bukan sekedar memahami ketidakadilan dalam distribusi kekuasaan dan distribusi resources, melainkan berupaya untuk membantu menciptakan kesamaan dan emansipasi dalam kehidupan. Studi kritis ini memiliki keterikatan moral untuk mengkritik status quo dan membangun masyarakat yang lebih adil (Raco, 2011). Tujuan pendekatan studi kritis adalah menghilangkan berbagai bentuk dominasi dan mendorong kebebasan, keadilan dan persamaan. Teori ini menggunakan metode reflektif dengan cara mengkritik secara terus-menerus terhadap tatanan kehidupan yang cenderung tidak kondusif bagi pencapaian kebebasan, keadilan, dan persamaan. Studi ini berupaya untuk menguak layar tiray realitas yang semu kemudian mengungkap hal apa yang sebenarnya terjadi di balik sesuatu yang tampak.

Studi kritis dalam penelitian ini tidak hanya untuk memaparkan kondisi riil sosial masyarakat namun juga berusaha merubah secara perlahan. Mengkritisi dan mempengaruhi dan mengubah hubungan sosial dengan cara mengungkap kondisi hubungan kekuasaan dan ketidakadilan. Pendekatan kritis dalam riset ini bertujuan untuk mengungkap hal-hal yang tersembunyi dalam kondisi praktek bisnis yang terjadi serta berkeinginan membebaskan masyarakat dari kondisi tersebut.

\section{Objek, Informan, Data dan Analisis}

Objek yang dipilih dalam penelitian ini adalah Perusahaan Daerah Air Minum di Kabupaten ABC. PDAM ABC ini merupakan salah satu perusahaan air yang memiliki kinerja keuangan (laba) yang rendah atau selalu mengalami kerugian. Dipilihnya PDAM ABC ini sebagai objek penelitian bukan bertujuan untuk men-generalisasi hasil penelitian ini untuk PDAM Indonesia. Namun lebih kepada pertimbangan agar substansi tidak terlepas dari fenomena rendahnya laba PDAM yang monopolis.

Informan dalam penelitian ini adalah seseorang yang dianggap mengetahui dan terlibat langsung dalam permasalahan laba (rugi) PDAM ABC. Pihak-pihak ini merupakan informan kunci yang terdiri dari jajaran manajemen PDAM ABC, tokoh masyarakat dan pelanggan. Dari pihak manajemen PDAM adalah jajaran manajemen antara lain: DM selaku Direktur Utama, KI selaku Direktur Keuangan dan Umum, JN selaku Direktur Tekhnik, GA selaku manajer akuntansi, LZ manajer 
tekhnik, LS manajer personalia. Data dalam penelitian ini bersifat data kuantitafif (data pendapatan) yang bersumber dari laporan keuangan perusahaan, catatan-catatan lain pendukung laporan keuangan. Selain itu data kualitatif diperlukan sebagai sumber informs untuk mengungkap makna di balik data kuantitatif pendapatan perusahaan. Data kualitatif inilah nantinya yang akan menjadi justifikasi dan argumentasi dalam mencari tahu keterkaitannya dengan angka pendapatan. Dengan demikian dalam penelitian kualitatif, pengumpulan data dalam realitas sosial yang terjadi tidak cukup dicari sampai apa yang menyebabkan realitas tadi (data kuantitatif), akan tetapi dicari sampai kepada makna di balik terjadinya realitas sosial yang tampak. Oleh karena itu, untuk dapat memperoleh makna dari realitas sosial yang terjadi, pada tahap pengumpulan data perlu dilakukan secara tatap muka langsung dengan individu atau kelompok yang dipilih sebagai responden atau informan yang dianggap mengetahui atau pahami tentang entitas tertentu seperti: kejadian, orang, proses, atau objek, berdasarkan cara pandang, persepsi, dan sistem keyakinan yang mereka miliki.

Peneliti akan mewawancarai beberapa pelanggan terpilih yang menggunakan produk PDAM ABC sesuai dengan kebutuhan data. Selain itu, untuk lebih melengkapi data penelitian dilakukan wawancara dengan pihak dewan (DPRD) Kabupaten $A B C$ yang merupakan representatif dari masyarakat kota dan menjadi pihak yang mengawasi jalannya roda pemerintahan, termasuk masalah pelayanan PDAM kepada masyarakat setempat. Sesudah memperoleh temuan awal yang disesuaikan dengan logika lapangan, kemudian peneliti membangun finding dalam bentuk hipotesahipotesa empirik. Kedekatan subjek studi dengan fokus studi merupakan kunci kesuksesan dalam riset ini sebagaimana dalam konsep value free. Hanya dengan kedekatan semacam inilah maka data yang diperlukan dapat diperoleh secara maksimal, temuan studi dianggap benar (Wirawan, 2006). Ana- lisis data dalam penelitian ini dilakukan sejak pertama kali tahap mengumpulkan data dilakukan terus berlanjut sampai penulisan penelitian. Data dan Informasi yang diperoleh dikumpulkan dan dikelompokkan berdasarkan subjek dicari kesesuaiannya. Selanjutnya sebagai pendukung pencarian makna di balik data peneliti akan mencari informasi kualitatif melalui wawancara dan diskusi dengan para informan.

\section{ANALISIS DAN PEMBAHASAN Perkembangan Angka Pendapatan}

Dalam perspektif ekonomi neoklasik yang menjadi objek kritik dari studi kritis menunjukkan bahwa angka pendapatan merupakan salah satu indikator kinerja perusahaan. Pendapatan memiliki porsi penting karena merupakan sumber utama pendanaan perusahaan selama proses operasi perusahaan (Hoogvelt dan Tinker, 1978). Pendapatan perusahaan yang senantiasa meningkat akan menjadi indikator bahwa perusahaan kinerjanya baik, namun sebaliknya angka pendapatan yang cenderung rendah menunjukkan kinerja perusahaan yang rendah. Namun demikian memandang pendapatan sejatinya tidak hanya sebatas pada nilai materi angka tersebut, namun yang tidak kalah pentingnya adalah pada aspek non materi dibalik angka pendapatan tersebut.

Data pendapatan perusahaan $\mathrm{ABC}$ dalam lima tahun terakhir sebagaimana disajikan pada Tabel 1. Terlihat bahwa tren perkembangan pendapatan perusahaan dari tahun ke tahun semakin mengalami perkembangan yang bagus dan kecederungan naik. Rata-rata kenaikan pertahun jumlah pendapatan yang dialami perusahaan mencapai $12 \%$. Hal ini menunjukkan kecenderungan kenaikan pendapatan yang positif dan menjadi indikator stabilitas profitabilitas perusahaan. Data kecenderungan rata-rata kenaikan pendapatan PDAM di Propinsi Jawa Timur dibandingkan dengan PDAM $A B C$ juga menunjukkan bahwa rata-rata kenaikan pendapatan PDAM ABC tergolong masih lebih tinggi (Tabel 2). 
Tabel 1

Perkembangan Pendapatan PDAM ABC

\begin{tabular}{ccc}
\hline \hline Tahun & Jumlah Pendapatan & $\%$ \\
\hline 2010 & $4,504,962,245.00$ & - \\
2011 & $5,322,619,310.00$ & $18 \%$ \\
2012 & $5,831,682,805.00$ & $10 \%$ \\
2013 & $6,358,038,335.00$ & $9 \%$ \\
2014 & $7,189,018,660.00$ & $13 \%$ \\
Rata-rata & $5,841,264,271.00$ & $12 \%$ \\
\hline
\end{tabular}

Sumber: Data laporan Keuangan perusahaan diolah

Tabel 2

Perbandingan Pendapatan PDAM ABC dan Jawa Timur

\begin{tabular}{ccccc}
\hline \hline Tahun & Rata-Rata Propinsi & \% & Rata-Rata PDAM. ABC & $\%$ \\
\hline 2010 & $3,765,934,500.00$ & - & $4,504,962,245.00$ & - \\
2011 & $4,104,868,605.00$ & $9 \%$ & $5,322,619,310.00$ & $18 \%$ \\
2012 & $4,556,404,151.55$ & $11 \%$ & $5,831,682,805.00$ & $10 \%$ \\
2013 & $5,194,300,732.77$ & $14 \%$ & $6,358,038,335.00$ & $9 \%$ \\
2014 & $5,661,787,798.72$ & $9 \%$ & $7,189,018,660.00$ & $13 \%$ \\
Rata-rata & $4,656,659,157.61$ & $\mathbf{1 1} \%$ & $\mathbf{5 , 8 4 1 , 2 6 4 , 2 7 1 . 0 0}$ & $\mathbf{1 2 \%}$ \\
\hline
\end{tabular}

Sumber: Data laporan keuangan diolah

Berdasarkan data-data pendapatan di atas menunjukkan bahwa angka pendapatan PDAM ABC memiliki kecenderungan meningkat dan rata-rata jumlah kenaikan pendapatan yang dihasilkan relatif lebih tinggi jika dibandingkan PDAM lainnya di Propinsi Jawa Timur pada umumnya. Hal ini sejalan dengan riset Shaoul (1997) yang menyatakan bahwa perusahaan publik memiki kecenderungan pendapatan yang tinggi.

\section{Mengungkap Makna Peningkatan Angka Pendapatan}

Dalam perspektif keuangan, tentu peningkatan pendapatan perusahaan sebagaimana tersaji sebelumnya menjadi indikator keberhasilan kinerja. Namun demikian jika dalam perspektif yang lebih utuh nampaknya tidak cukup menilai kinerja suatu perusahaan dari aspek keuangan saja. Untuk lebih melengkapinya diperlukan penilaian lain misalnya dalam perspektif pelanggan, proses bisnis internal dan lainnya (Werner, 2012; Erwin dan Prabowo, 2015; Widhiyaningrat dan Idayati, 2015; Ramadhani dan Trisyulianti, 2016). Pemahaman angka pendapatan secara lebih utuh akan lebih lengkap jika dikaji tidak hanya aspek keuangan namun juga pada pemahaman makna dan kepentingan di balik angka pendapatan tersebut.

Pertama, Kenaikan Tarif Sebagai Jalan Pintas Untuk Mengejar Pendapatan

Dalam perspektif studi kritis memahami pendapatan berarti mengungkap makna dibalik angka tersebut. Kecenderungan meningkatnya pendapatan secara materi bisa dirasakan oleh seluruh pihak di perusahaan. Disamping dipahami secara materi, pendapatan yang dihasilkan perusahaan juga dimaknai dari sudut pandang non materi baik dari sudut pandang psikologis maupun sosial. Dengan demikian sebagaimana dalam pendekatan kritis pada penelitian ini, akan 
dilakukan penilaian lebih lanjut pada aspek makna (non materi) dibalik angka pendapatan perusahaan. Pendapatan bagi manajemen sangat penting maknanya dalam menjalankan usaha perusahaan. Ini berarti bahwa tanpa ada pendapatan maka niscaya perusahaan akan mampu menutup seluruh beban operasional.

Untuk mampu meningkatkan pendapatan suatu perusahaan maka strategi peningkatan tarif rekening air terus diupayakan dan dilaksanakan secara regular (Bradbury, 2005; Pratama et al., 2013). Dalam pandangan manajemen PDAM ABC, pendapatan itu tidak bisa dilepaskan dari strategi kenaikan tarif sebagaimana Direktur Teknik menyatakan bahwa:

Pendapatan PDAM bisa terus naik tiap tahun karena faktor tarif yang selalu kami atur. Tiap dua tahun sekali pasti kami lakukan penyesuaian. Jika tanpa kenaikan tarif tentu PDAM ini tidak bisa berkutik menutup operasional dan perawatan instalasi air yang sangat besar.

Selama saya berada di sini kami tidak bisa membuat kebijakan lain. Pernah mencoba membuat produk baru AMDK, tapi hasilnya hingga kini malah membebani keuangan perusahaan. Kondisi alam di kota ini tidak bisa dibandingkan dengan kota lain, di tempat lain bisa memiliki strategi selain menaikkan tarif.

Jadi pendapatan bagi informan ini diidentikkan dengan strategi kenaikan tarif. Hal ini bisa terjadi karena bagi manajemen khususnya, strategi ini adalah satu-satunya cara yang bisa dilakukan secara berkala. Senada dengan pernyataan di atas Direktur Keuangan mengungkapkan makna pendapatan sebagai berikut:

Pendapatan PDAM tidak bisa dilepaskan dari tarif. Saya sangat berkepentingan dengan strategi tarif ini. PDAM di kota berbeda dari kota lain, kota ini gersang dan tandus. Jika kami naikkan tarif maka pendapatan PDAM akan naik pula dan sebaliknya. Hal itu kami lakukan setiap dua tahun sekali. Bagi kami pendapatan tidak bisa ditingkatkan dengan tanpa kenaikan tarif. Tarif bagi kami adalah strategi yang tepat, karena meningkatkan omset juga tidak bisa karena keterbatasan sumber air. Sudah sering kami perhatikan bahwa jika pada tahuntahun tidak ada kenaikkan tarif maka tidak ada kenaikkan yang signifikan. Tapi sedikit aja ada kenaikan maka otomatis kenaikan pendapatan akan serta merta terjadi.

Berdasarkan data tarif yang ada menunjukkan bahwa memang kenaikan tarif secara rutin telah dilakukan manajemen tiap dua tahun sekali. Oleh karena itu tidak heran jika dalam benak kedua direktur ini pendapatan salah satunya bermakna "kenaikan tarif". Grafik 1 menunjukkan bahwa tingkat kenaikan penjualan air dalam rupiah ( $R p)$ jauh lebih pesat daripada kenaikan penjualan dalam meter kubik $\left(\mathrm{m}^{3}\right)$. Hal ini berarti bahwa kenaikan penjualan tidak didukung dengan kenaikan jumlah meter kubik yang terjual. Strategi kenaikan tarif dua tahun sekali (Tabel 3) dan pengaruhnya terhadap penjualan berdasarkan data di atas dibenarkan oleh pihak Direktur Keuangan dan Umum PDAM ABC dalam sebuah kesempatan wawancara:

Sumber kenaikan pendapatan yang kita peroleh lebih banyak dipengaruhi oleh penyesuaian tarif dan itu sangat besar dampaknya pak bagi kami dalam mencukupi biaya operasional yang juga terus meningkat. Kita bisa mendapatkan kenaik an pendapatan dengan menaikkan tarif, karena untuk menaikkan debit air terjual kepada pelanggan kita belum bisa.

Berdasarkan data keuangan perusahaan, diketahui bahwa pendapatan perusahaan lebih banyak disebabkan faktor kenaikan tarif dari pada faktor omset penjualan. Hal ini bisa dilihat bahwa pada tahun-tahun tarif dinaikkan, kecenderungan yang terjadi ada- 


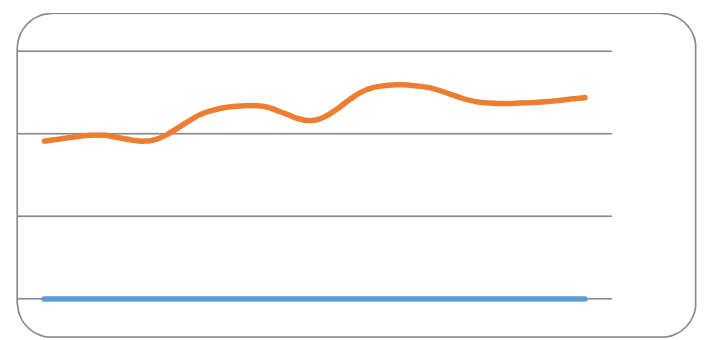

Penjualan air dalam $\mathrm{m}^{3}$

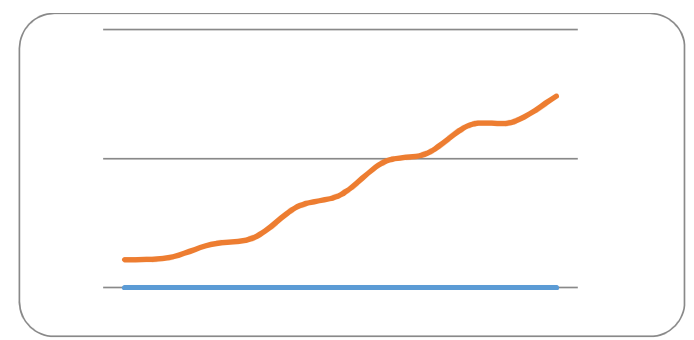

Penjualan akir dalam Rp.

Grafik 1

Perbandingan Kenaikan Penjualan Air

(Dalam $\mathrm{m}^{3}$ dan $\mathrm{Rp}$ )

Tabel 3

Perkembangan Tarif dan Penjualan $m^{3}$ PDAM ABC

\begin{tabular}{ccccc}
\hline \hline Tahun & Tarif (Rp) & Kenaikan & Penjualan $(\mathbf{m} 3)$ & Kenaikan \\
\hline 2009 & $1.583,33$ & $0 \%$ & 2.169 .000 & $-7 \%$ \\
2010 & $2.165,00$ & $37 \%$ & 2.548 .000 & $17 \%$ \\
2011 & $2.165,00$ & $0 \%$ & 2.575 .000 & $1 \%$ \\
2012 & $2.496,67$ & $15 \%$ & 2.392 .000 & $-7 \%$ \\
2013 & $2.496,67$ & $0 \%$ & 2.382 .000 & $0 \%$ \\
2014 & $2.810,00$ & $13 \%$ & 2.443 .605 & $3 \%$ \\
\hline & Rata-rata & $39 \%$ & Rata-rata & $3 \%$ \\
\hline
\end{tabular}

Sumber: Data Tarif dan Penjualan PDAM ABC

lah penjualan mengalami peningkatan signifikan dibandingkan dengan penjualan tahun sebelumnya. Hal ini sebagaimana hasil penelitian Sauqi dan Albintani (2013), Malawat dan Putra (2016) bahwa perusahaan cenderung lebih banyak menggunakan elemen tarif untuk meningkatkan pendapatan.

Kebenaran bahwa memang tarif menjadi fokus perjuangan perusahaan meningkatkan pendapatan dibenarkan oleh Direktur Umum perusahaan:

Kenaikan tarif PDAM adalah satusatunya cara saat ini bagi perusahaan untuk dalam meningkatkan pendapatan, oleh karena itu kami berusaha sekuat tenaga meloloskan kenaikan tarif dua tahun sekali. Sangat mudah pak bagi kami dalam menaikkan tarif itu. Ya kami tinggal diskusi dan rapat dengan anggota dewan (DPR) dan tentu kami memberikan sesuatu kepada mereka, bereslah semua urusan.
Secara pribadi saya memang berat menggunakan strategi tarif ini, tapi apa mau dikata dari dulu memang tarif yang menjadi solusinya. Kita tidak punya pilihan atau opsi lain yang bisa digunakan. Kondisi alam di sini tidak memungkin dibandingkan dengan di Malang misalnya.

Kenaikan tarif sebagai "senjata utama" dan dilakukan secara berturut-turut memang memungkinkan bagi perusahaan. Bentuk perusahaan yang monopoli sangat mendukung, dan ada jaminan bahwa pelanggan tidak akan beralih ke perusahaan lain. Perusahaan bisa dengan leluasa menentukan berbagai macam strategi untuk meningkatkan kinerja mereka. Strategi kenaikan tarif yang dimainkan manajemen perusahaan untuk meningkatkan pendapatan idealnya harus mengikuti aturan yang telah ditetapkan pemerintah. Diperlukan suatu strategi peningkatan pendapatan dengan tidak hanya dari satu cara yaitu 
kenaikan tarif. Oleh karena itu perlu pengaturan atau manajemen kenaikan tarif yang tidak membebani pelanggan atau kenaikan tarif diimbangi dengan pelayanan yang bagus (Utama, 2010; Indayani dan Sunarto, 2013; Anandasari, 2016; Sandhyavitri et al., 2016). Tranparansi dan akuntabilitas adalah salah satu prinsip yang ditentukan dalam peraturan pemerintah. Transparansi mengandung maksud bahwa dalam proses penetapan tarif semua dasar dan alasan-alasan yang logis diungkapkan kepada publik. Akuntabilitas mengandung makna bahwa penetapan yang melalui proses transparansi ini nantinya akan dipertanggungjawabkan kepada masyarakat.

Namun demikian, karena PDAM ABC ini merupakan perusahaan monopoli, dan posisinya sebagai price setter maka kondisi ideal itu sulit untuk dilakukan. Realitasnya, penentuan tarif atau harga air minum sepenuhnya menjadi kekuasaan manajemen perusahaan, dan pihak konsumen tidak memiliki kekuatan untuk menolak. Sifat monopoli dapat membuat perusahaan berlaku semena-mena dalam menentukan tarif. Prinsip transparansi dan kejujuran sudah tidak lagi dipertimbangkan, yang utama adalah pendapatan naik. Realitas di atas sepenuhnya terjadi di perusahaan, sebagaimana dinyatakan Manajer Keuangan dan Umum:

Selama ini tidak ada mekanisme musyawarah dengan pihak konsumen, kalaupun ada dengan perwakilan rakyat (DPRD) itu hanya musyawarah untuk memenuhi syarat administrasi saja. Pada kenyataannya DPRD hanya sebagai tempat "ngobrol" dan pada akhirnya semua terpulang kepada pihak perusahaan. Kami sudah lima kali menaikkan tarif. Kenaikan tarif kami lakukan setiap dua tahun sekali. Selama itu pula memang banyak pertentangan dari konsumen, namun kami selalu bisa mengatasi masalah itu bersama dengan anggota DPRD. Kami sudah terbiasa rembuk-rembuk masalah tarif dengan DPRD.

Bagi perusahaan monopoli, strategi peningkatan tarif secara berulang menunjukkan penggunaan kekuasaan (power) manajemen untuk memperoleh pendapatan secara "otoriter". Penggunaan strategi ini dapat pula menjadi indikasi ketiadaan inovasi produk dan strategi penjualan yang berkualitas dan arif dari manajemen. Ujungujungnya kualitas manajemen perlu dipertanyakan kemampuan untuk mengelola perusahaan secara sehat. Sebenarnya jika manajemen punya niat dan keinginan yang sungguh-sungguh untuk memperbaiki citra perusahaan banyak cara yang bisa dilakukan. Beberapa strategi yang dapat dilakukan antara lain penguatan produk utama dan usaha ekspansi. Upaya penguatan bisnis utama dengan melakukan strategi penjualan berbasis omset atau kuantitas penjualan air (meter kubik $/ \mathrm{m}^{3}$ ). Penjualan bisa ditingkatkan dengan perluasan cakupan pelayanan dan memanfaatkan tingkat kehilangan air yang ada. Ini dilakukan mengingat adanya keterbatasan sumber bahan baku air yang dimiliki PDAM ABC. Selain itu perlu terus dilakukan efisiensi biaya-biaya yang tidak bernilai tambah. Usaha-usaha ekspansi dapat dilakukan dengan cara menciptakan inovasi produk baru guna menunjang pendapatan perusahaan. Usaha ekspansi itu misalnya bisnis air minum dalam kemasan (AMDK), membuka usaha kolam renang, kolam pancing, dan lain sebagainya.

Usaha AMDK sebenarnya sangat menarik dilakukan secara serius karena peluang keberhasilannya cukup tinggi. Kondisi monopoli perusahaan sebagai milik Pemda dimanfaatkan secara maksimal, yaitu memasarkan 'secara paksa" produk AMDK kepada institusi-institusi pemerintah daerah. Mulai dari tingkat kelurahan sampai pada institusi DPRD dan Pemda. Sebagai perusahaan milik daerah upaya ini tidak sulit dilakukan hanya bergantung pada keinginan dan kemauan dari pihak manajemen dan Pemda sebagai pemilik perusahaan. 


\section{Kedua, Pendapatan: Kewajiban Setor PAD Pada Pemda}

Persepsi bahwa perusahaan memiliki kewajiban untuk menaikkan dan atau mempertahankan jumlah pendapatan setiap bulan adalah hal yang wajar. Jumlah beban langsung maupun tidak langsung perusahaan yang melampaui pendapatan memberikan Implikasi bagi manajemen untuk wajib mencari pendapatan agar mampu menutup beban dan memenuhi kewajiban menyetor PAD kepada Pemda. Sebagaimana dinyatakan sang Direktur Keuangan:

Pendapatan wajib hukumnya naik atau paling tidak tetap, dibandingkan dengan tahun sebelumnya. Jika pendapatan turun sudah pasti kami kerepotan sendiri karena banyak pos-pos pengeluaran yang harus ditanggung. Oleh karena itu wajib bagi kami untuk mempertahankan kenaikan agar terus bertahan.

Oleh karena itu makna angka pendapatan kedua adalah "kewajiban setoran PAD kepada Pemda". Ketika pendapatan PDAM meningkat maka hal itu berbanding lurus dengan jumlah PAD yang harus disetor kepada Pemda ABC. Hampir seluruh informan yang diminta pendapat sepakat dengan hal ini, sebagaimana dalam pernyataannya:

Pendapatan meningkat berarti setoran PAD kita juga pasti meningkat. Karena Pemda biasanya akan minta PAD berdasarkan hasil pendapatan yang diperoleh. Sebaliknya jika tidak terlalu besar pendapatan maka setoran PAD juga demikian.

Pemda itu seperti punya mata-mata di perusahaan ini. Mereka tahu saja berapun jumlah pendapatan yang kita hasilkan. Pemda sangat berkepentingan dengan setoran PAD. Karena itu kita selalu rutin membayar PAD kepada Pemda.

Wajarlah bagi kami menyetor PAD ke Pemda, perusahaan ini kan punya Pemda. Oleh karena itu saya juga komitmen untuk memberikan setoran sebagai bentuk kontribusi kami kepada Pemda. Ingat ini juga bentuk penilaian bagi Direksi.

Setoran dana PDAM ke Pemda merupakan salah satu sumber penerimaan PAD yang memang sangat diharapkan. Terlebih lagi di daerah bukan industri seperti di ABC, PDAM menjadi satu-satunya badan usaha milik pemerintah daerah yang mampu memberikan kontribusi yang sangat signifikan terhadap PAD. Berdasarkan data, sesungguhnya PDAM ini tidak layak untuk menyerahkan setoran PAD nya. Dalam konsepnya setoran PAD akan dilakukan jika perusahaan mengalami laba, sebagaimana dalam penelitian Pariyatin (2014), Lasari (2016), Sugiarto (2016), dan Muhtarom (2015). Kenyataan di lapangan bahwa meski kondisi rugi perusahaan tetap diharuskan memberikan setoran PAD (lihat Tabel 4). Inilah realitas yang terjadi, PDAM ABC masih mampu membayar PAD selama bertahun-tahun meski dalam kondisi rugi terus. Tentu selama itu pula beban keuangan perusahaan semakin bertambah.

Berdasarkan data keuangan PDAM ABC pada Tabel 4 jumlah setoran PAD perusahaan ke pemda dalam lima tahun terakhir rata-rata mencapai angka Rp 119.300.000 pertahun. Padahal pada tahun yang bersamaan jumlah kerugian yang dialami perusahaan juga besar. Jadi ada kesan bahwa setoran ini diwajibkan dalam kondisi apapun. Nampak bahwa pihak PDAM sendiri tidak memiliki pilihan selain menyetor dana ke PAD Pemda.

Sehubungan dengan "wajibnya" perusahaan menyetor PAD ini dua informan Direktur Umum dan Kepala Bagian Umum dan Keuangan, secara seragam menyatakan:

Kita ini perusahaan milik Pemda, kalau tidak setor PAD itu jadi bumerang buat pimpinan pak. Bisabisa kita dipecat untuk mengelola perusahaan ini. Setoran PAD kami jadi ukuran kinerja bagi pimpinan PDAM. Jika tidak setor atau setoran- 
nya kecil itu jadi pertanyaan besar bagi Pemda kepada kami.

Saya tahu semestinya dalam kondisi rugi perusahaan tidak perlu setor PAD ke Pemda. Tapi itu bentuk kompromi kami ke Pemda agar terus bisa di bantu dan dijamin keberlangsungan perusahaan ini. Dan juga untuk menunjukkan kinerja kita bahwa PDAM punya kontribusi ke PAD Pemda.

Tabel 4

Perbandingan Setoran PAD dan Kerugian PDAM

\begin{tabular}{|c|c|c|}
\hline Tahun & PAD & Kerugian \\
\hline 2010 & 120.000 .000 & $(875.235 .826)$ \\
\hline 2011 & 132.000 .000 & $(615.633 .155)$ \\
\hline 2012 & 140.000 .000 & (309.481.508) \\
\hline 2013 & 87.500 .000 & $(729.294 .576)$ \\
\hline 2014 & 117.000 .000 & (320.539.745) \\
\hline Rata-rata & 119.300 .000 & \\
\hline
\end{tabular}

Berdasarkan informasi ini memang pihak perusahaan merasa tidak enak untuk tidak menyetor ke PAD. Padahal menurut Permendagri Nomor 13 Tahun 2006 tentang Pedoman Pengelolaan Keuangan Daerah, Pasal 26 huruf 3 (a) menyebutkan bahwa:

"Jenis hasil pengelolaan kekayaan daerah yang dipisahkan sebagaimana dimaksud pada ayat (1) huruf $c$ dirinci menurut obyek pendapatan yang mencakup: (a) bagian laba atas penyertaan modal pada perusahaan milik daerah/BUMD; (b) bagian laba atas penyertaan modal pada perusahaan milik pemerintah/BU$\mathrm{MN}$; dan (c) bagian laba atas penyertaan modal pada perusahaan milik swasta atau kelompok usaha masyarakat".

Jadi berdasarkan peraturan menteri dalam negeri tersebut setoran PAD baru bisa dilakukan jika perusahaan mengalami laba. PAD bersumber dari bagian laba perusahaan bukan dari bagian rugi perusahaan. Dalam penelitian Mustika dan Idayati (2014), Fitriani et al. (2015), Muhtarom (2016), dan Anggraini et al. (2017) dinyatakan bahwa PAD diperoleh dari bagian keuntungan
BUMD bukan kerugian. "Keterpaksaan" perusahaan menyetor PAD kepada Pemda ini mendapat sorotan dari Ketua Perpamsi Ir H.Achmad Marjo Kudri, dalam suatu kesempatan:

Berdasarkan peraturan yang baru Perusahaan Daerah Air Minum (PDAM) tidak ada kewajiban menyetorkan keuntungan bagi peningkatan Pendapatan Asli Daerah (PAD). Karena dalam undangundang Badan Usaha Milik Daerah (BUMD) tahun 2010, PDAM masuk dalam Perusahaan Umum Daerah (Perumda), bukan Persero.

Dalam peraturan tersebut PDAM masuk dalam Perumda, bila masuk Perumda maka PDAM tidak ada kewajiban harus memberikan keuntungan untuk peningkatan PAD. Melainkan berdasarkan ketentuan tersebut keuntungan harus dikembalikan ke dalam perusahaan, sebagai investasi dalam upaya peningkatan pelayanan kepada publik. Setoran PAD bagi jajaran direksi PDAM $\mathrm{ABC}$ merupakan indikator keberhasilan mereka dalam mengelola perusahaan secara 
nyata. Jika mereka tidak mampu memenuhi target dari sang penguasa, maka direksi akan merasa aman dalam status quo nya. Namun sebaliknya, mereka akan terus-menerus waswas jika target setoran PAD tidak tercapai. Begitulah yang dirasakan oleh Direktur Keuangan PDAM ABC mewakili jajaran direksi perusahaan. Ini merupakan konsekuensi politis dan logis bagi mereka sebagai direksi yang diangkat oleh penguasa setempat. Penguasa tentu punya kepentingan dengan setoran PAD dari PDAM, karena hal itu merupakan penunjang keberhasilan sang penguasa dalam menjalankan roda pemerintahan di Kabupaten ABC. Terlebih lagi perusahaan daerah di sana relatif terbatas dan lebih mengandalkan PDAM sebagai sumber pendapatan PAD dari badan hukum.

\section{Ketiga, Mengejar Pendapatan: Pelang- gan Turut Menderita}

Meningkatnya pendapatan perusahaan dalam perspektif studi kritis tidak cukup hanya diukur dari seberapa besar dan seberapa lama peningkatan pendapatan itu dihasilkan oleh perusahaan. Lebih dari sekedar itu, pendekatan kritis memahami peningkatan pendapatan pada sejauh mana keadilan yang menjadi cita-cita ditetapkan atas pengelolaan ekonomi umat (Guo et al., 2009). Keadilan yang dimaksud adalah terciptanya iklim usaha yang memiliki manfaat positif, berkeadilan dan distribusi yang merata bagi seluruh pihak. Tidak hanya terbatas pada pihak-pihak yang langsung berkontribusi kepada perusahaan namun juga pihak lain yang tidak langsung berkontribusi, termasuk pula keadilan bagi alam sekitar.

Meningkatnya pendapatan PDAM setiap tahun bagi pelanggan bukanlah suatu kejutan. Pendapatan PDAM logikanya akan naik terus sebagai konsekuensi dari peningkatan tarif yang dilakukan secara rutin. Namun demikian, bagi pelanggan yang terpenting adalah apakah kenaikan pendapatan perusahaan telah memperhatikan aspek keadilan pelayanan bagi pelanggan atau malah sebaliknya? Fakta tentang penegakan keadilan dalam perusahaan menunjukkan bahwa kenaikan pendapatan perusahaan setiap tahun justru cenderung membebani para pelanggan dan tidak diikuti dengan komitmen tinggi meningkatkan pelayanan. Hal ini sejalan dengan penelitian Ali dan Rusli (2014) bahwa masih dijumpai beberapa kasus di mana PDAM mengabaikan pelayanan dan kepentingan pelanggan, keluhan pelanggan sering tidak ditanggapi dengan baik oleh perusahaan. Semua ini menandakan bahwa memang kedudukan antara konsumen dan produsen tidak setara. Dengan kata lain kinerja pendapatan perusahaan hanya ditujukan pada kepentingan perusahaan semata, sedangkan stakeholders lain (utamanya pelanggan) kurang mendapatkan perhatian.

Angka pendapatan yang terus meningkat di perusahaan dengan demikian bisa dimaknai "penderitaan pelanggan." Hal ini dapat dilihat dari kenyataan bahwa pendapatan tinggi justru membuat pelanggan menderita. Sejalan dengan yang dinyatakan Soelasih (2014) bahwa pemaknaan pendapatan sebagai penderitaan bagi pelanggan tidak lain karena dampak kenaikan tarif yang selalu meningkat. Hal serupa juga dinyatakan beberapa pelanggan:

Jika tarif air ini terus dinaikkan yang untung jelas perusahaan. Pendapatannya akan naik, namun bagi saya malah sebaliknya. saya cukup menderita dengan kenaikan tarif ini. Tiap malam saya begadang nungguin air PDAM keluar. Enak bagi perusahaan, pendapatannya makin meningkat. Terus terang saya belum dapat kompensasi dari perusahaan atas meningkatnya pendapatan mereka, sudah cukuplah masyarakat ini menderita dengan kenaikkan tarif.

Disudut kota lainnya seorang informan bernama As memberikan pendapat lain atas kualitas pelayanan PDAM. Pelanggan 
senantiasa berada dalam posisi tawar yang sangat lemah karena sebagai pihak yang sangat membutuhkan produk dari PDAM tersebut.

Saya sempat memarahi petugas pencatat rekening air PDAM. Bagaimana tidak, tetangga saya memiliki jumlah anggota keluarga yang lebih banyak dari pada jumlah anggota keluarga saya dan pemakaian yang relatif sama. Namun yang terjadi justru pembayaran rekening air saya lebih tinggi dari rekening air tetangga. Harusnya hitungan dari jumlah anggota keluarga biaya pemakaiannya lebih banyak.

Saat ketemu petugas catat saya sedikit mengancam si petugas pencatat meter air dengan berbagai macam dalih, dan ternyata ancaman saya cukup ampuh hasilnya. Pada bulan berikutnya jumlah tagihan rekening saya jauh lebih rendah daripada bulan-bulan sebelumnya.

Rupanya petugas pencatat meter air selama ini menurut bapak ini mencatat meteran setiap rumah menggunakan "ilmu hisab" yaitu ilmu kira-kira untuk lebih mempercepat tugas mencatat meter air setiap pelanggan dan kemudian dibuat perkiraan setiap bulan jumlahnya sama.

Fakta lain bahwa sebenarnya peningkatan pendapatan PDAM justru membuat pelanggan terbebani justru didukung oleh pihak legislatif (Ketua komisi B) Bapak IR yang telah melakukan upaya sidak langsung kepada para pelanggan di beberapa daerah jaringan PDAM.

Pelanggan mengeluhkan aliran air bersih ke rumahnya. "Air PDAM ke rumah mereka baru bisa keluar saat jam 10 malam hingga pagi. Selebihnya, tidak ada air yang mengalir lagi. Tapi kalau pembayarannya, tetap membayar Rp 62 ribu perbulan, padahal meteran air sudah lama tidak berfungsi.
Puluhan Kepala Keluarga (KK) mengeluhkan penerapan tarif air PDAM yang diberlakukan. Pasalnya, pelayanan PDAM tidak berbanding lurus dengan tarif yang selama ini diberlakukan. Selama 2 bulan, puluhan KK membayar tarif air bersih tanpa adanya air yang mengalir ke tiap rumah mereka.

Pelanggan tetap membayar penuh meskipun aliran air ke rumahnya sangat sedikit. Bahkan air PDAM terkadang ngadat. Kadang satu hari tidak ada air yang masuk ke rumah pelanggan.

Hasil sidak di tempat lain oleh anggota DPRD menunjukkan bahwa pendapatan PDAM sepanjang tahun memang meningkat namun pelanggan tetap melarat. Beberapa hasil investigasi DPRD langsung ke pelanggan sebagaimana diuraikan oleh Ketua komisi B DPRD ABC Bapak IR berikut:

Hasil sidak pertama di salah satu kecamatan oleh Komisi B DPRD $A B C$ bertujuan untuk mengetahui apakah pemberlakuan tarif yang dinilai terlalu tinggi menjadi keluhan masyarakat. Selama ini masyarakat pelanggan mengeluh, seorang pelanggan sebelum adanya kenaikan tarif, mereka ada yang membayar Rp 40 ribu. Namun, saat ini mereka harus mengeluarkan $\mathrm{Rp} 98$ ribu dan itu telah berlangsung selama 4 bulan. Pelanggan tetap membayar penuh meskipun aliran air ke rumahnya sangat sedikit. Bahkan air PDAM terkadang ngadat. "Kadang satu hari tidak ada air yang masuk ke rumah pelanggan. "Sejumlah pelanggan tetap mengeluhkan pemberlakuan tarif yang tidak sesuai dengan jumlah pemakaian serta pelayanan yang diberikan PDAM ke pelanggan".

Karena merasa bahwa tarif PDAM sangat tinggi dan tidak diimbangi dengan peningkatan pelayanan kepada para pelang- 
gan, maka pihak legislatif melalui Ketua Komisi B DPRD setempat berupaya untuk menekan pihak PDAM agar melakukan perbaikan dan penyesuaian seperlunya.

"DPRD mengancam akan mempidanakan Perusahaan Daerah Air Minum (PDAM) jika memberlakukan tarif dasar air minum beserta pelayanan yang diberikan kepada 9 ribu pelanggan yang tersebar di 13 kecamatan tidak segera diperbaiki. Bahkan Dewan juga tidak akan segan-segan memberikan rekomendasi pada Bupati jika pemberlakuan tarif masih saja diberlakukan. Pasalnya, hampir secara keseluruhan, pelanggan PDAM banyak mengeluhkan penerapan tarif dasar yang telah diberlakukan.

Dari beberapa fakta di atas menjelaskan bahwa kenaikan pendapatan sebagai dampak kenaikan tarif memiliki dampak positif bagi perusahaan. Namun kenaikan itu belum dapat diimbangi dengan penegakan keadilan bagi pihak pelanggan. Pelanggan merasakan ketidakadilan dalam pelayanan sebagai konsekuensi kenaikan tarif yang telah ditetapkan oleh perusahaan. Ketidak adilan yang dirasakan oleh pelanggan ini bisa dilihat dari banyaknya keluhan atas pelayanan PDAM pasca kenaikan tarif. Dengan kata lain kemaslahatan bagi pelanggan belum dapat dipenuhi oleh manajemen.

Kondisi ini sejalan dengan yang dinyatakan Muhtarom (2016); Hidayati et al. (2016) bahwa selama ini perusahaan memiliki kecenderungan mengabaikan pelayanan kepada pelanggan. Sebaliknya perusahaan malah lebih mengutamakan pendapatan dibandingkan memberi pelayanan terbaik kepada pelanggan.

Kondisi ideal adalah kenaikan pendapatan akibat tarif harus diikuti peningkatan pelayanan. Artinya bahwa ketika tarif dinaikkan maka pelayanan juga harus diimbangi. Prinsipnya, tarif harus menguntungkan kedua belah pihak. Pelayanan yang baik telah menjadi isu strategis karena berimplikasi dalam perbaikan kepercayaan publik pada pemerintah (Endarti, 2011; Rachmiatie et al., 2015; Afrizal, 2016; Puspitasari, 2016). Pelanggan harus dibela, perusahaan pun harus dibela. Membela perusahaan pun sebetulnya membela kepentingan rakyat. Kalau perusahaan tak mampu lagi beroperasi, yang rugi tentu pelanggan juga. Tidak ada air berarti tidak bisa mencuci, tidak mandi dan tidak ada aktivitas kebersihan.

\section{Keempat, Keadilan Alam dan Lingku- ngan yang Terabaikan}

Setiap perusahaan tidak dilarang untuk berusaha sekuat tenaga dalam meningkatkan pendapatan. Tentu usaha-usaha ini dibenarkan secara hukum dan tidak menimbulkan kerugian bagi pihak lain dan lingkungan sekitarnya. Dengan kata lain keberadaan perusahaan akan dapat memberikan kemanfaatan (kemaslahatan) bagi stakeholders. Kemaslahatan bisa diwujudkan dalam bentuk memberikan kesejahteraan dan keadilan tidak hanya bagi manusia namun juga berlaku bagi alam sekitar (Triyuwono, 2006: 189). Selain pihak yang langsung berhubungan dengan bisnis perusahaan, juga pihak yang tidak berhubungan langsung misalnya lingkungan alam sekitar (Ruslan dan Alimuddin, 2012; Hidayat et al., 2011).

Sebagai perusahaan yang mengolah sumber daya alam, PDAM tentu setiap saat bersentuhan dengan alam dan lingkungan. Untuk itu, di samping bisa mengelola sumber daya air sebagai bahan baku, perusahaan juga harus bisa mengelola polusi atau kerusakan yang timbul dari proses produksi (penyedotan) sumber air. Termasuk pula kerusakan yang ditimbulkan akibat penggalian sambungan pipa air bersih yang tertanam di bawah tanam dan jalan-jalan. Sebagai konsekuensi pekerjaan, pada saat pembongkaran dan perawatan harus memperhatikan dan menghindari dampak negatifnya. Sebagaimana dalam penelitian Bastian, (2012); Setiawan, (2016); dan Utama (2016) menyatakan bahwa perusahaan tidak bisa serta merta meninggalkan dampak- 
dampak yang ditimbulkan dan hanya fokus pada upaya peningkatan pendapatan semata. Sehubungan dengan masalah ini, tampaknya PDAM ABC masih mengalami beberapa kendala. Banyak keluhan masyarakat atas kerusakan jalan-jalan perkotaan di Kabupaten ABC sebagai akibat pekerjaan saluran air. Jalan rusak dibiarkan setelah digali, air mengalir dan menggenang karena bocor, lubang-lubang penggalian tidak ditutup kembali, adalah beberapa contoh dampak yang belum mendapat perhatian serius perusahaan.

Dalam survey lapangan terdapat contoh lokasi dimana seorang polisi lalu lintas unit Dikyasa Satuan Lalu Lintas ABC melakukan rekayasa lantas terhadap jalan berlubang. Lokasi yang terletak di Jl. SGR ini terjadi usai adanya galian pipa air yang dilakukan oleh PDAM setempat. Kemudian pada salah satu contoh lokasi di sudut kota lain yang mengalami kerusakan kebocoran air PDAM selama beberapa waktu lamanya. Kelalaian perusahaan terhadap kelestarian lingkungan ini sebenarnya hanya masalah kurang koordinasi perusahaan dengan pihak yang berwenang. Kurangnya koordinasi ini dibenarkan bapak AR, salah seorang informan dan pengawas jalan Dinas Pekerjaan Umum Kabupaten ABC yang secara kebetulan bertemu saat mengawasi perbaikan jalan akibat ada bekas galian.

"Sebagai salah satu pengawas jalan dinas PU Bina Marga, saya menyoroti tindak lanjut pekerjaan pembongkaran jalan akibat pemasangan pipa yang dilakukan oleh PDAM. Saya sangat mendesak pihak PDAM untuk senantiasa memperbaiki kembali jalan-jalan yang rusak pasca pembongkaran. Hasil pengawasan terhadap jalan-jalan di daerah ini menunjukkan bahwa masih banyak ditemui jalan yang belum diperbaiki.

Fakta yang ada bahwa pembongkaran salah satu sisi jalan, guna memasang pipa air bersih PDAM, telah membuat beberapa ruas jalan di Kabupaten ini rusak dan bergelombang. Idealnya pihak PDAM sendiri memperbaiki kembali jalanjalan tersebut dengan pengaspalan ulang. Namun seperti saat ini anda lihat ternyata pihak PDAM tidak memperbaiki kerusakan jalan akibat pembongkaran pipa, justru dari pihak kami sendirilah yang memperbaikinya.

Selanjutnya bapak AR sebagai pihak yang mewakili PU dalam menilai kelalaian PDAM untuk memperbaiki kembali jalan yang rusak menyatakan bahwa:

"Galian pipa yang dilakukan oleh PDAM selama ini dilakukan tanpa koordinasi dengan pihak kami. Akibatnya, pihak kami merasa kelabakan dan sering dikeluhkan masyarakat. Setelah jalan digali, terus dibiarkan begitu saja, sehingga menyebabkan jalan menjadi rusak dan berlubang. Kedepan harapan saya tentu pihak PDAM akan melakukan koordinasi yang lebih intensif dengan dinas PU agar setelah penggalian dapat secepat mungkin dilakukan pengaspalan, sehingga jalan-jalan yang mengalami pembongkaran kembali berfungsi seperti sedia kala

Beberapa fakta yang dikumpulkan dari beberapa media menyatakan bahwa maraknya galian aliran air PDAM di perkotaan membuat Dinas Pekerjaan Umum (PU) Bina Marga JT juga berang. Pasalnya, PDAM ABC dituding tidak berkoordinasi ketika menggali di tengah jalan. Bahkan, PU Bina Marga Jatim menilai kinerja perusahaan pelat merah itu tidak profesional. Selain tanpa ada koordinasi, setelah digali PDAM mengabaikan keselamatan pengguna jalan dengan membiarkan kubangan di tengah jalan, hal ini disampaikan oleh salah satu pengawas jalan:

"Pada dasarnya maksud PDAM baik, demi memberi pelayanan terbaik kepada konsumennya, namun, tindakan perusahaan milik pemkab 
itu terkesan tidak menghargai PU Bina Marga. Alasannya, perusahaan penyuplai air bersih itu cenderung hanya bisa merusak jalan, tapi tidak bisa mengembalikan seperti kondisi semula. "Ini (kubangan bekas perbaikan aliran air) juga perlu disoroti, karena menggangu pengguna jalan. Apalagi, tiba-tiba ada kubangan yang sebelumnya kami tidak tahu,". Bukan hanya di sini (Jalan Kabupaten) tapi masih banyak lainnya. Memang tugas kami adalah memperbaiki jalan. Tapi, ya mbok kami diberi tahu. Sebab, jika terjadi kecelakaan akibat kubangan itu, kami yang disalahkan," keluhnya

Tidak hanya masyarakat umum yang peduli terhadap dampak galian pemasangan sambungan air di jalan umum, pihak kepolisian sebagai pihak yang mengatur jalan raya juga memberikan perhatian khusus agar pihak perusahaan (PDAM) senantiasa memperhatikan perawatan kembali bekas galian sambungan air. Hal ini sebagaimana telah dikemukakan oleh seorang anggota Lantas Polres setempat Bapak Sd dalam sebuah kesempatan.

"Hasil rekayasa lantas terhadap jalan berlubang ditemukan dilokasi yang terletak di Jl. Segara. Ini muncul usai adanya galian pipa air yang dilakukan oleh PDAM setempat beberapa waktu lalu. Lokasinya terletak tepat didepan SLTPN 4 yang merupakan jalur utama masuk kota. Kami langsung mengambil dokumentasi terhadap jalan rusak yang memiliki tingkat kepadatan sangat tinggi ini.

Sebagai langkah awal akan kami teruskan kepada instansi yang terkait dengan jalan supaya ada upaya perbaikan. Kami semaksimal mungkin berperan terhadap kepentingan masyarakat khususnya pengguna jalan, "supaya masyarakat nantinya dapat berkendara dengan nyaman dijalan".
Direktur Teknik PDAM ABC, ditemui secara terpisah mengakui adanya keluhankeluhan terkait bekas galian jalan raya. Secara terbuka beliau mengatakan:.

"Kami sebenarnya telah berusaha mengantisipasi keluhan terkait bekas galian dan genangan air bocor. Kami berusaha mengingatkan karyawan di lapangan untuk peduli membenahi bekas galian-galian itu. Tapi mungkin karena keterbatasan tenaga dan dana dari perusahaan sehingga tidak bisa optimal. Selain itu memang selama ini belum ada koordinasi yang baik pihak kami dengan dinas PU. Semoga kedepan hubungan ini akan lebih baik lagi.

Beberapa permasalahan lingkungan akibat galian jalan dan air sumber di atas menjadi bukti kurang pedulinya perusahaan terhadap lingkungan. Peningkatan pendapatan menjadi lebih diunggulkan dan melupakan kewajiban sebagai konsekuensinya. Perusahaan harus lebih arif dan bijak dalam mengejar peningkatan pendapatan. Pendapatan yang terus meningkat penting bagi perusahaan, namun dampak sampingan untuk menghasilkan pendapatan tetap harus menjadi perhatian. Keadilan bagi lingkungan tetap harus dijaga dan tidak boleh dikesampingkan.

\section{SIMPULAN DAN SARAN}

Hasil kajian dengan menggunakan studi kritis dalam mengungkap rahasia atau makna dibalik meningkatnya angka pendapatan perusahaan menemukan: (1) Peningkatan angka pendapatan ternyata tidak bisa dilepaskan dari kepentingan manajemen dan pemilik perusahaan. Angkaangka tersebut merupakan refleksi dari berbagai kepentingan yang ada. Jadi ini adalah fakta bahwa angka akuntansi tidak bisa dilepaskan dari kepentingan; (2) Bahwa angka pendapatan yang tinggi bermakna dengan adanya strategi kenaikan tarif. Artinya untuk meningkatkan pendapatan maka 
itu "hanya" dilakukan dengan meningkatkan tariff semata. Langkah yang lain tidak pernah dipikirkan oleh manajemen. Hal ini bisa terjadi karena bagi manajemen strategi ini adalah satu-satunya cara yang bisa dilakukan secara berkala; (3) Angka pendapatan yang tinggi bermakna "kewajiban setoran PAD kepada Pemda". Karena faktor kewajiban menyetor inilah yang menjadikan perusahaan mau tidak mau harus memperoleh pendapatan dengan cara bagaimanapun. Jika setoran tidak ada maka ini identik dengan kinerja mereka tidak baik dimata Pemda; (4) Bahwa meningkatnya pendapatan ternyata bermakna penderitaan bagi pelanggan. Ketidakadilan yang dirasakan oleh pelanggan ini bisa dilihat dari banyaknya keluhan atas pelayanan PDAM pasca kenaikan tariff; (5) Keadilan, kelestarian terhadap lingkungan patut juga menjadi pertimbangan dan tidak boleh diabaikan dalam meraih pendapatan yang tinggi.

Penggunaan studi kritis dalam riset akuntansi belum banyak dilakukan. Oleh karena itu di masa depan perlu terus dikembangkan dan diadaptasikan dengan situasi dan kondisi objek penelitian. Sehingga studi ini akan lebih bisa berkembang secara konsep dan praktis. Berdasarkan keterbatasan penelitian yang ada serta mengingat pentingnya penelitian dengan model ini maka di masa yang akan datang diperlukan penelitian yang berupaya membandingkan pemahaman dan penilaian kinerja untuk dua atau lebih perusahaan sejenis, dan tentunya dengan periode penelitian lapangan yang lebih baik.

\section{DAFTAR PUSTAKA}

Afrizal. 2016. Paradigma Baru Birokrasi Pemerintahan Dalam Mewujudkan Tata Kelola Pemerintahan Yang Baik. Kemudi, Jurnal Ilmu Pemerintahan 1(1): 1-23.

Agustianto, A. 2013. Komunikasi Dalam Dominasi Budaya Teori Kritis Menurut Jurgen Habermas. Jurnal Ilmu Budaya 9(2): 75-83.

Ali, W. dan Z. Rusdi. 2014. Analisis Kinerja Pelayanan Perusahaan Air Minum
(PDAM) Kota Dumai. Jurnal Ekonomi 22(2).

Anandasari, Y. 2016. Analisis Dampak Penentuan Tarif Air Perusahaan Daerah Air Minum (PDAM) Terhadap Kinerja Keuangan Perusahaan Daerah Air Minum (PDAM) (Studi pada PDAM Tulungagung dan PDAM Kabupaten Malang). Jurnal Ilmiah Mahasiswa FEB Universitas Brawijaya 3(1).

Anggraini, V., K. Hidayati, dan T. Lestari. 2017. Pengaruh Penerimaan Pajak Daerah, Retribusi Daerah dan Hasil Laba BUMD Terhadap Pendapatan Asli Daerah (PAD) Kota Surabaya. Jurnal Ekonomi Akutansi 3(3): 854-866.

Apriyanti, H. W. 2017. Akuntansi Syariah: Sebuah Tinjauan Antara Teori dan Praktik. Jurnal Akuntansi Indonesia 6(2): 131-140.

Bailey, D. T. 1988. Accounting in Socialist Countries. Routledge. London.

Bastian, A. 2012. Balanced Scorecard Sebagai Indikator Pengelolaan Sumber Daya Alam. Jurnal Ilmiah Mahasiswa Akuntansi 1(2): 51-56.

Batubara, J. 2017. Paradigma Penelitian Kualitatif dan Filsafat Ilmu Pengetahuan dalam Konseling. Jurnal Fokus Konseling 3(2): 95-107.

Beaver, W. H. 1966. Financial Ratios as Predictors of Failure. Jurnal of Accounting Research 5(1966): 71-111.

Bradbury, K. 2005. Regional Differences in the Impact of Energy Price Increases. FRB of Public Policy Brief No. 05-1.

Brown, P. dan R. Ball. 1967. Some Preliminary Finding on the Association between the Earning of a Firm, Its Industry and the Economy. Journal of Accounting Research 5(1967): 55-77.

Burchell, S., C. Clubb, dan A. G. Hopwood. 1985. Accounting in its Social Context: Towards a History of Value Added in the United Kingdom. Accounting, Organizations, and Society 10(4): 381-413.

Burrel, G. dan G. Morgan. 1979. Sociological Paradigms and Organisational Analysis: 
Elements of the Sociology of Corporate Life. Heinemann Educational Books. London. Chua, W. F. 1986. Radical Developments in Accounting Thought. The Accounting Review 61(4): 601-632.

Demirovic, A. 2009. Foucault, Gramsci and Critical Theory-Remarks on their Relationship. Technical University. Berlin. Cultural Political Economy Research Centre (CPER). http://www.lancaster.ac.uk/fass/ centres/cperc/docs/CR-Demirovic-Foucault. $p d f$.

Donatus, S. K. 2015. Teori Kritis dan Relevansinya Untuk Pengkajian Terhadap Realitas Sosial Bangsa Indonesia. Jurnal Ledalero 14(1): 159-181.

Endarti, E. W. 2011. Kebijakan Publik dan Reformasi Administrasi: Studi Kasus pada Kabupaten Jimbaran Bali. Governance: Jurnal Kebijakan dan Manajemen Publik 2(1): 1-10.

Erwin dan H. Prabowo. 2015. Analisis Pengukuran Kinerja Menggunakan Metode Balanced Scorecard pada PT. Bahtera Utama. Binus Business Review 6(1): 35-45.

Fitriani, P. E., W. Cipta, dan I. K. Kirya. 2015. Analisis Rasio Efektivitas dan Kontribusi Laba Perusahaan Daerah Terhadap Pendapatan Asli Daerah Kabupaten Buleleng Tahun 2009-2013. e-Journal Bisma Universitas Pendidikan Ganesha Jurusan Manajemen 3(1).

Francis, J. R. 1990. After Virtue? Accounting as a Moral and Discursive Practice. Accounting, Auditing and Accountability Journal 3(3): 5-17.

Gamble, A. 1995. The New Political Economy. Political Studies 43(3): 516-530.

Guo, L., J. J. Xiao, dan C. Tang. 2009. Understanding the Psychological Process Underlying Customer Satisfaction and Retention in a Relational Service. Journal of Business Research 62(11): 11521159.

Hidayat, G., S. Susanriana, dan Y. Fiscal. 2011. Analisa Sistem Informasi Akuntansi Dalam Pengendalian Intern Penjualan dan Piutang (Study Kasus pada
CV. Alam Prima Komputer (Sentra Laptop) di Bandar Lampung). Jurnal Akuntansi \& Keuangan 2(2): 233-246.

Hidayati, S., A. Baequny, dan Sumarni. 2016. Faktor-Faktor yang Berpengaruh terhadap Kepuasan Pasien pada Pelayanan Pengobatan TB Paru di BKPM Kota Pekalongan. Jurnal Litbang Kota Pekalongan 10(2016): 11-21.

Hines, R. D. 1988. Financial Accounting: in Communicating Reality, We Construct Reality. Accounting, Organization, and Society 13(3): 251-261.

Hoogvelt, A. M. M. dan A. M. Tinker. 1978. The Role of the Colonial and PostColonial States in Imperialism - A CaseStudy of the Sierra Leone Development Company. The Journal of Modern African Studies 16(1): 67-79.

Hopwood, A. G. 1978. Towards an Organizational Perspective for the Study of Accounting and Information Systems. Accounting, Organizations, and Society 3(1): 3-13.

Ikatan Akuntan Indonesia. 2016. Standar Akuntansi Keuangan. Salemba Empat. Jakarta.

Indayani, I. P. dan Sunarto. 2013. Analisis Kelayakan Tarif Air Berdasarkan Peraturan Menteri Dalam Negeri Nomer 23 Tahun 2006 Data Tahun 2009 s.d 2012 Studi di PDAM Tirta Dharma Kabupaten Sleman. Jurnal Akuntansi 1(2): 6073.

Irianto, G. 2006. Privatisasi BUMN Di Indonesia: Pilihan atau Keniscayaan? Telaah dari Perspektif PEA. Proceeding, The Second Postgraduate Consortium on Accounting 2006. Brawijaya University Malang.

Iwan. 2014. Menelaah Teori Kritis Jurgen Habermas. Jurnal Edueksos III(2): 145165.

Juliandi dan Manurung. 2014. Metodologi Penelitian Bisnis: Konsep dan Aplikasi. Edisi Pertama. UMSU Press. Medan.

Jurdi, S. 2011. Sosiologi Islam dan Masyarakat Modern, Teori, Fakta, dan Aksi Sosial. Prenada Media Grup. Jakarta. 
Komala, A. R. 2015. Kajian atas Perbedaan atas Akuntansi Konvensional dengan Akuntansi Syariah (Review antar Jurnal). Jurnal Riset Akuntansi VII(2): 2334.

Kieso, D. E., J. J. Weygandt, T. D. Warfield. 2014. Intermediate Accounting: IFRS Edition. Richard D. Irwin, Inc. Illionois.

Lasari, N. N. D. 2016. Kontribusi Pajak Daerah dan Retribusi terhadap Pendapatan Asli Daerah (PAD) Kabupaten Karangasem Tahun 2011-2015. Jurnal Program Studi Pendidikan Ekonomi 8(3): 1-10.

Mackevicius, J. 2005. The Triumph and Fall of Socialist Accounting: a Historical Aspect. Economics 72: 38-53.

Malawat, M. S. dan M. U. M. Putra. 2016. Kajian Kebijakan Tarif Listrik Pemerintah terhadap Konsumen Ditinjau dari Tingkat Pendapatan Masyarakat di Kabupaten Asahan. Jurnal Wira Ekonomi Mikroskil 6(02): 141-148.

Mulawarman, A. D. 2013. Nyanyian Metodologi Akuntansi Ala Nataatmadja: Melampaui Derridian Mengembangkan Pemikiran Bangsa "Sendiri". Jurnal Akuntansi Multiparadigma JAMAL 4(1): 149-164.

Muhtarom, A. 2015. Analisis PAD (Pendapatan Asli Daerah) terhadap Kesejahteraan Masyarakat Kabupaten Lamongan Periode Tahun 2010-2015. Jurnal EKBIS XIII(1): 659-667.

Muhtarom, A. 2016. Analisis Pendapatan Asli Daerah Sektor Perusahaan Daerah di Kabupaten Lamongan. Jurnal Ekonomi dan Studi Pembangunan 8(1): 61-71.

Mustika, W. A. dan F. Idayati. 2014. Kontribusi Pajak Daerah dan Retribusi terhadap Pendapatan Asli Daerah di Pemerintah Kota Surabaya. Jurnal Ilmu dan Riset Akuntansi 3(6): 1-24.

Nurhayati. 2015. Melukiskan Akuntansi Dengan Kuas Interpretif. Jurnal Bisnis dan Manajemen Islam 3(1): 174-191.

Pariyatin, Y. 2014. Optimalisasi Kinerja Perusahaan Daerah untuk Meningkatkan PADS dalam Menunjang Otonomi
Daerah. Jurnal Kalibrasi Sekolah Tinggi Teknologi Garut 12(1): 1-11.

Pratama, I. W. D. Y., I. N. Norken, dan I. P. G. S. Pariartha. 2013. Analisis Perubahan Penggunaan Air Minum Sebelum dan Setelah Kenaikan Tarif PDAM Kota Denpasar (Studi Kasus: Denpasar Selatan). Jurnal Ilmiah Elektronik Infrastruktur Teknik Sipil 2(2): 1-6.

Priyastiwi. 2016. Pengaruh Budaya Terhadap Akuntansi, Auditing dan Praktik Akuntansi Internasional. Jurnal Riset Manajemen 3(1): 78-95.

Puspitasari, N. L. dan I. K. G. Bendesa. 2016. Analisis Kualitas Pelayanan Publik di Badan Pelayanan Perijinan Terpadu Kabupaten Badung. E-Jurnal Ekonomi dan Bisnis Universitas Udayana 5(1): 89114.

Rachmiatie, A., D. Ahmadi, dan E. Khotimah. 2015. Dinamika Transparansi dan Budaya Badan Publik Pasca Reformasi Birokrasi. Jurnal Sosiohumaniora 18(3): 268-274.

Raco, R. 2011. Metode Penelitian Kualitatif. PT. Gramedi Widiasarana. Jakarta.

Ramadhani dan E. Trisyulianti. 2016. Perancangan Balanced Scorecard sebagai Pengukuran Kinerja pada PT. Asuransi MSIG Indonesia. Jurnal Manajemen dan Organisasi VII(2): 140-153.

Riyansyah, A. 2017. Pemikiran Sofyan Syafri Harahap Tentang Akuntansi Syariah dan Penerapannya. AT-TAFAHUM: Journal of Islamic Law 1(2): 12-24.

Ruslan, M. dan Alimuddin. 2012. Makrifat Akuntansi, Determinasi Puncak Perjalanan Spiritualitas Akuntansi: Suatu Tinjauan Ontologis. Jurnal Akuntansi Multiparadigma 3(3): 357-367.

Sandhyavitri, A., N. R. Putri, M. Fauzi, dan S. Sitikno. 2016. Analisis Kesediaan Masyarakat Untuk Membayar (Willingness to Pay) Biaya Pengadaan Air Bersih di Kota Pekanbaru. Jurnal Teknik Sipil dan Perencanaan 2(18): 75-86.

Sauqi, Y. R. dan M. Albintani. 2013. Tinjauan Ekonomi Politik Badan Usaha Milik 
Daerah. Jurnal Demokrasi dan Otonomi Daerah 11(2): 123-128.

Shaoul, J. 1997. A Critical Financial Analysis of the Performance of Privatised Industries: The Case of the Water Industry in England and Wales. Critical Perspectives on Accounting 8(5): 479-505.

Setiawan, T. 2016. Penerapan Akuntansi Manajemen Lingkungan pada Dua Puluh Lima Perusahaan yang Terdaftar di Indeks Sri Kehati 2013. Jurnal Akuntansi 2(9): 110-129.

Setijaningsih, H. T. 2012. Teori Akuntansi Positif dan Konsekuensi Ekonomi. Jurnal Akuntansi XVI (03): 427-438.

Setyosari, P. 2016. Metode Penelitian Pendidikan dan Pengembangan. Cetakan 5. Penerbit Prenada Media Grup. Jakarta.

Soelasih, Y. 2014. Pengaruh Kualitas Pelayanan dan Kewajaran Tarif terhadap Nilai Konsumen serta Retensi Pelanggan untuk Penerbangan Domestik Niaga Full Services di Indonesia. Jurnal KINERJA 18(1): 1-21.

Sugiarto, E. 2016. Analisis Kontribusi Perusahaan Daerah Pasar terhadap Peningkatan Pendapatan Asli Daerah di Kabupaten Lamongan. Jurnal EKBIS XV(1): 772-781.

Sugiono, A. 2014. Merekonstruksi Akuntansi Sebagai Upaya Internalisasi Nilai-Nilai Spiritualitas. Wacana Equiliberium, Jurnal Pemikiran Penelitian Ekonomi 2(01): 1-15.

Tinker, A. M. 1980. Towards a Political Economiy of Accounting: An Empirical Illustration of the Cambridge Controversies. Accounting, Organizations, and Society 5(1): 147-160.
Tinker, A. M., B. D. Merino, dan M. D. Neimark. 1982. The Normative Origins of Positive Theories: Ideology and Accounting Thought. Accounting, Organizations, and Society 7(2): 167-200.

Triantoro, A. 2008. Praktek Akuntansi dalam Budaya Kapitalisme. Jurnal Fokus Ekonomi 3(1): 60-76.

Triyuwono, I. 2000. Organisasi dan Akuntansi Syariah. LKIS. Yogyakarta.

Triyuwono, I. 2006. Perspektif, Metodologi, dan Teori Akuntansi Syariah. PT. Raja Grafindo Persada. Jakarta.

Utama, C. 2010. Manajemen Kenaikan Tarif PAM untuk Peningkatan Akses Air Bersih bagi Seluruh Masyarakat. Jurnal Adminsitrasi Bisnis 6(2): 146-159.

Utama, A. A. G. S. 2016. Akuntansi Lingkungan Sebagai Suatu Sistem Informasi: Studi Pada Perusahaan Gas Negara (PGN). Jurnal Bisnis dan Manajemen 6(1): 89-100.

Watts, R. L. dan J. L. Zimmerman. 1986. Positive Accounitng Theory. Prentice Hall Inc.

Werner, M. L. 2012. Executing Strategy with the Balanced Scorecard. International Journal of Financial Research 3(1): 88-94.

Wirawan, I. B. 2014. Teori-Teori Sosial dalam Tiga Paradigma. Cetakan Keempat. Penerbit Prenada Media Grup. Jakarta.

Widhiyaningrat, W. A. dan F. Idayati. 2015. Pengukuran Kinerja Organisasi Nirlaba dari Perspektif Balanced Scorecard pada Rumah Sakit Umum Haji Surabaya. Jurnal Ilmu dan Riset Akuntansi 4(6): 1-20. Yusuf, M. 2016. Metode Penelitian Kuantitatif dan Kualitatif dan Penelitian Gabungan. Penerbit Prenada Media. Jakarta. 